\title{
導電性フィラーを用いた電磁波シールド材の 最近の進歩
}

高濱 裕 宣* 戸来稔雄**

\section{1. は じめに}

近年, コンピュータ, ワープロ, スイッチング電源等 のデジタル技術を応用した製品から発生する電磁波が社 会的な問題となっている. 米国 FCC (連邦通信委員会), 西独 VDEをはじめとして, 欧米各国では電磁波障害 (以下 EMI) 飞対する規制の実施，強化を行っている. わが国では, 電気通信技術審議会が, 国際無線障害委員 会(CISPR)の勧告をもとに昭和56年度から審議を開始 し, 昭和 60 年12月, 「情報処理装置から発生する妨害波 及び妨害高周波電流の許容值及び測定法」に関する技術 規格を取りまとめ郵政大臣に答申した。この答申を受け て, 郵政省は, 関連業界に対して指導といら形で段階的 な EMI 対策に着手した。通産省の指導のもとに, 昭和 60 年12月, 関連 4 団体は「情報処理装置等電磁波障害 自主規制協議会」(VCCI)を設立した、VCCI の許容値 は, 第 1 種装置(工業用, 商業用として使用されるも の. 汎用コンピュター, 業務用ワープロ), 第 2 種装置 (住宅地域で使用されるるの. パソコン, ワープロ)によ って異なり，正規許容值を達成するまで暫定期間が設け られている. 表 1 飞第 2 種装置の許容值を示す ${ }^{(1)}$. 緩 和措置期間も昭和 63 年11月で終了し, VCCI 規制值も 完全実施が行われ, 電磁波シールド材の開発は最終段階 を迎えている。

*(森)スリーディコンポリサーチ研究員

** 新日本製鉄(侏)第一技術研究所化学研究センター主 幹研究員

Recent Progress in the Electro-magnetic Shielding Materials with Conductive Fillers; Hironobu Takahama*, Toshio Herai** (*Three-D Composites Research Corporation, Tsukuba. ${ }^{* *} \mathrm{R} \& \mathrm{D}$ Laboratories-I, Nippon Steel Corp., Kawasaki)

Keywords: electro-magnetic shielding, composites, filler, conductive, thermoplastics, shielding effectiveness, electro-magnetic interference, percolation, aspect ratio 1988年12月16日受理
EMI 対策の手段は，以下のように大別され，技術的， 経済的に最適な手段が単独あるいは複数を組み合わせて 選択される。

(1) 回路設計での対策(回路パターンの設計) ${ }^{(2)}$.

（2）フィルター等の対策部品の付加による対策(お 与に伝導性妨害電波に対処) ${ }^{(3)}$.

（3）電磁波シールド性筐体による対策(放射性妨害 電波に対処).

現在用いられている樹脂製筐体に電磁波シールド性を 付与する方法としては, 表面に導電性被膜を形成する方 法と, プラスチックの中に導電性フィラーを充填する方 法がある(4)(5). 種々の方法の特徵を表 2 に示す。本稿 に执いてはこの導電性フィラーを充填した成形材料の最 近の研究, 開発状況について述べる.

\section{2. 電磁波シールドとは}

\section{（1）シールド効果の理論}

金属板の電磁波シールド効果に対して, Schelkunoff が理論的考察を行っている(6).

$$
\text { シールド効果 }(\mathrm{dB})=\text { 反射損失 }+ \text { 吸収損失 }
$$$$
\text { 十多重反射損失 }
$$

\section{(a) 反射損失 $(\boldsymbol{R})$}

反射損失とは，電磁波の伝播経路中に媒質の異なる境 界面が存在すると, 両者の波動インピーダンスが異なる ために電波の一部が境界面で反射され進入する電磁波エ ネルギーが失われる．電界成分が大きい場合(高インピ 一ダンス) と磁界成分が大きい場合 (低インピーダンス) とでは損失の程度が異なる.

電界の場合：

$$
R(d B)=346+6 \log _{10}\left(\sigma / f^{3} \cdot \mu \cdot r^{2}\right)
$$

磁界の場合 :

$$
\begin{aligned}
R(\mathrm{~dB})= & 20 \log _{10}(0.182 / r \sqrt{\mu / f \cdot \sigma} \\
& +0.136 \sqrt{f \cdot \sigma / \mu}+0.354)
\end{aligned}
$$


表 1 第 2 種情報装置に対する漏洩電波の許容値.

\begin{tabular}{c|c|c|c|c|c|c}
\hline \hline $\begin{array}{c}\text { 自主規制ステップ } \\
\text { 周波数範囲 }\end{array}$ & \multicolumn{2}{|c|}{$\begin{array}{c}\text { 61年6月-62年 } 5 \text { 月に } \\
\text { 初めて製造される装置 }\end{array}$} & \multicolumn{2}{|c|}{$\begin{array}{l}\text { 62年6月-63年11月に } \\
\text { 初めて製造される装置 }\end{array}$} & \multicolumn{3}{|c|}{$\begin{array}{l}\text { 63年12月以降に製造 } \\
\text { される装置 }\end{array}$} \\
\hline (測定距離) & $(10 \mathrm{~m})$ & $(3 \mathrm{~m})$ & $(10 \mathrm{~m})$ & $(3 \mathrm{~m})$ & $(10 \mathrm{~m})$ & $(3 \mathrm{~m})$ \\
\cline { 2 - 8 } & $40 \mathrm{MHz}-230 \mathrm{MHz}$ & $50 \mathrm{~dB}$ & $34 \mathrm{~dB}$ & $44 \mathrm{~dB}$ & $30 \mathrm{~dB}$ & $40 \mathrm{~dB}$ \\
$230 \mathrm{MHz}-1000 \mathrm{MHz}$ & $47 \mathrm{~dB}$ & $57 \mathrm{~dB}$ & $41 \mathrm{~dB}$ & $51 \mathrm{~dB}$ & $37 \mathrm{~dB}$ & $47 \mathrm{~dB}$ \\
\hline
\end{tabular}

注 $1: 1 \mu \mathrm{V} / \mathrm{m}$ を $1 \mathrm{~dB}$ とする.

注 $2:$ 測定距離は $30 \mathrm{~m}, 10 \mathrm{~m}, 3 \mathrm{~m}$ のいずれかひとつでよい.

ただし, 測定距離 $3 \mathrm{~m}$ の值は, $1 \mathrm{~m}$ 以下の装置に適用する.

表 2 プラスチックの電磁波シールド方法.

\begin{tabular}{|c|c|c|c|c|}
\hline 分 & シールド方法 & 物 & 特 & 徵 \\
\hline 表面処理方法 & $\begin{array}{l}\text { 導電性塗料 } \\
\text { 無電界メッキ } \\
\text { 丞着 } \\
\text { 亜鉛溶射 }\end{array}$ & $\begin{array}{l}\text { (1)低コスト } \\
\text { (1)高シールド性 } \\
\text { (1)高シールド性 } \\
\text { (1)高シールド性 }\end{array}$ & $\begin{array}{l}\text { (2)複雑な形状には不均一 } \\
\text { (2)高度な技術を要する } \\
\text { (2)複雑形状には不均一 } \\
\text { (2)作業環境悪い }\end{array}$ & $\begin{array}{l}\text { (3)作業性悪い } \\
\text { (3)高ュスト } \\
\text { (3)高コスト } \\
\text { (3)密着性悪い }\end{array}$ \\
\hline 複合的方法 & 導電性プラスチック & (1)低コスト & (2)従来成形法を踏襲 & (3)化粧塗装必要 \\
\hline
\end{tabular}

ここで

$f:$ 周波数 $(\mathrm{Hz})$

$r:$ 放射源とシールド材間の距離 $(\mathrm{m})$

$\sigma:$ 銅に対する比導電率

$\mu$ :銅に対する比透磁率

\section{(b) 吸収損失 $(A)$}

吸収損失とは，電波が媒質中を伝播していく経路中で 渦電流としてェネルギーが失われることによるものであ り，媒質中の電磁波に対する電波定数を計算することに より得られる。

$$
A(\mathrm{~dB})=3.34 t \sqrt{f \cdot \sigma \cdot \mu}
$$

ここで

$$
t: \text { シールド材の厚さ }(\mathrm{m})
$$

\section{(c) 多重反射損失 (B)}

多重反射損失はシールド材内部の両境界面での反射の 繰り返しによるものであり，反射損失と吸収損失の和が 十分に大きい場合無視できる.

上記の式から，電界のシールドを目的とする場合には 高電気伝導性材料を，磁界のシールドには高透磁率材料 を用いなければならないことが分かる。しかし，この理 論は低周波電磁波に対する金属板のシールドに関するも のである、樹脂内部に導電性フィラーを分散させたシー ルド材は，金網に近い構造を有し，乙かも $1 \mathrm{MHz}$ を越 える高周波領域についての適用には若干問題がある。し かしながら，シールド効果と導電性のあいだには密接な 関係が知られて括り，高い導電性材料を用いることで高 い電磁波シールド特性が得られる(図 1)。

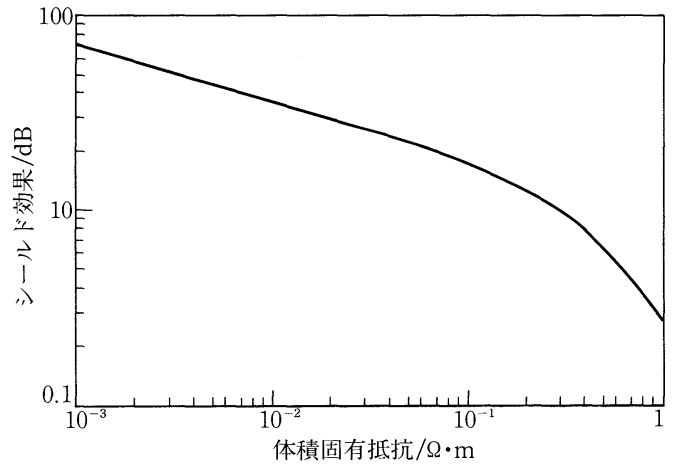

図 1 体積固有抵抗とシールド効果. (平面波, $1 \mathrm{GHz})^{(7)}$
（2）パーコレーション理論

樹脂に導電性フィラーを添加することにより, 複合体 の電気伝導性, 熱伝導性が大きく变化する ${ }^{(8)}$. 導電性〉 ィラーを樹脂に混合するとき，導電性フィラーの充填量 を増してゆくと最初, 非常に僅かな体績固有抵抗の減少 がみられる。市る臨界充填量 (臨界体積分率： $V_{\mathrm{f}}^{*}$ ) で複 合体の体積固有抵抗が転移的に減少し，10桁以上の減 少がみられその後再び緩やかな減少に戻る(図 2).

この転移的な体積固有抵杭の減少は, 導電性フィラー が樹脂マトリクス中で㠜集を開始し，導体回路を作り始 めることに対応している。この回路ができる現象をパー コレーションと称する， $V_{f}^{*} は$, 樹脂内での導電性フィ ラーの分散状態の変化を示す. $V_{\mathrm{f}}^{*}$ の導電率への影響に 関する理論計算としてはモンテカルロ法(9)-(11), 確率計 


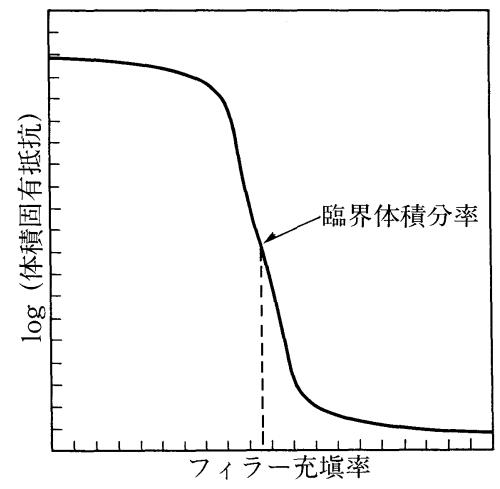

図 2 体積固有抵抗の体積分率依存性 ${ }^{(9)}$

算法 (12) (13), 統計的解析 (14) 等が行われている. その結 果, $V_{\mathrm{f}}^{*}$ は導電性フィラーのアスペクト比(長さ/径)の 自乗に逆比例する ${ }^{(10)}$.

$$
\mathrm{V}_{\mathrm{f}}^{*} \infty(1 / \text { アスペクト比 })^{2}
$$

従って, 分散させる導電性フィラ一の形状は, 粉末ょり も箔, 箔よりも繊維のほうがより少ない添加量で十分な 導電性が得られる.

$\mathrm{V}_{\mathrm{f}}^{*}$ は, 使用する樹脂の物性によっても変化する，樹 脂の接着性が高い汇ど, $\mathrm{V}_{\mathrm{f}}^{*}$ は増大する.これは, 接着 性が高いと導電性フィラーの界面を濡らし接触抵抗を増 大させる(9)(12)(15)(16) だけでなく，樹脂との混練時にフィ ラーの構造破壊が起こるためである(17). 樹脂の粘度が 高い場合も， $\mathrm{V}_{\mathrm{f}}^{*}$ は増大寸る ${ }^{(18)}$ 。これは高い粘度のため に，樹脂との混練時に繊維破損を引き起こすためであ る、樹脂の結晶化が $V_{f}^{*}$ の増加を引き起こすことも知ら れている(19)-(21).

導電性粉末が均一分散した場合の，理論 $\mathrm{V}_{\mathrm{f}}^{*}$ 值は35体 積\%である．樹脂の粒子径と導電性粉末の粒子径を一定 比に保ち, 凝集構造を持たせて複合体を成形した場合, $\mathrm{V}_{\mathrm{f}}^{*}$ 值は 5 体積\%まで低減することができる(19)．導電 性炭素粉末ケッチェンブラックは，他の炭素粉末と比較 して, 極端に少ない添加量で優れた導電性を発現する。 これは樹脂との混練成形後も, ケッチェンブラックが特 異な高次構造を保ち得ることによるものである(22). 導 電性シールド材の開発においては, 導電性フィラーの均 一な分散よりも, 効率のよい電気的回路の形成こそ必要 となる。

以上のことから導電性フィラーとしては,

（1）アスペクト比の高い繊維形状をしたもの.

（2）成形工程で凝集構造が破損しないもの.

（3）金属並の導電性を有するもの.

に絞られる。しかし，優れた電磁波シールド材を開発す るらえで，最適な導電性フィラーの選択のみならず， 、 トリクスとなる樹脂の選択，樹脂との混練法を含めた成 形法についても検討を加えなければならない.
3. 成 形 法

\section{(1) コンパウンド方式}

より少ない繊維の混入量でより良い導電性を持たせる ためには可能な限り長い繊維状のフィラーを混入するこ とが望ましい，乙かし，樹脂に金属繊維を練り込むコン パウンド方式を採用した場合，押出機，射出成形機 2 段階のスクリュウ剪断を受け，成形品中の金属繊維は破 断し，高いアスペクト比を保てない(23)(24)(図 3).

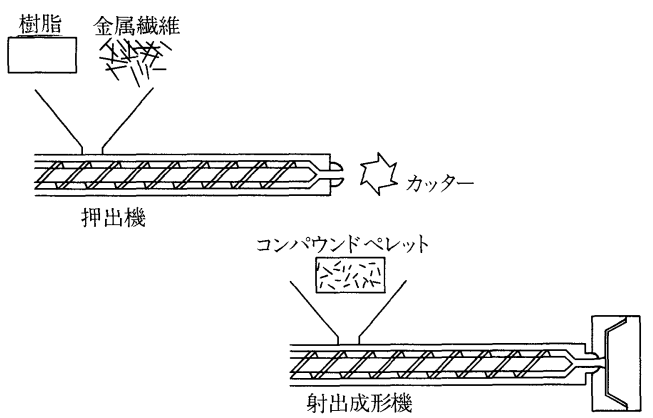

図３コンパウンド方式の工程.

（2）マスターペレット方式

マスターペレット方式は, 連続繊維に樹脂を連続含浸 させた後，任意の長さに切断しマスターペレットを製造 する.このマスターペレットは，ペレット長とほぼ等し い長さの金属繊維を高密度に含有し，これを一般樹脂ぺ レットと混合し，射出成形内で分散させ成形する．この 方式によれば，スクリュウの混練が一度で済み，成形品 中により長い繊維を保つことができる(7)(25)(26)(図 4).

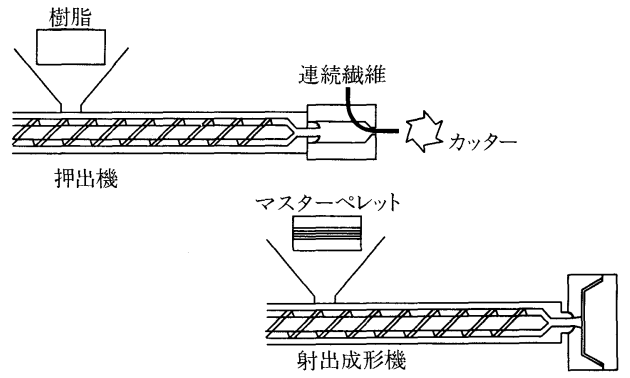

図4 マスターペレット方式の工程.

\section{4. 各種導電フィラー}

電磁波シールド成形材料の要求特性としては, 電界の 
シールド効果が $40 \mathrm{~dB}$ 以上，アイゾット衝撃強さ(ノッ チ付) $0.8 \mathrm{Nm} / \mathrm{cm}$ 以上，および在来の金型および成形機 がそのまま使用できることである(27). $40 \mathrm{~dB}$ のシールド 効果を得るには体積固有抵抗で $10^{-3} \Omega \cdot \mathrm{m}$ 程度を達成す る必要がある(26)(28)(29)．以下に，現在市販されている導 電性フィラーの概要について述べる. 現段階では, シー ルド効果, 体積固有抵抗の測定法は確立していない. 従 って, 各社から出されている測定結果だけから, 導電性 フィラーの優劣の決断を下すのは難しい.

\section{（1）びびり振動切削法繊維}

東大生産技術研究所，中川教授によって開発された新 しい金属繊維である(30). 図 5 にびびり振動切削法によ る金属繊維の生産方式を示す，材質としては，鋼，銅，

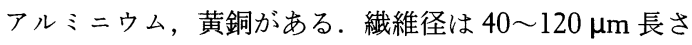
2 15 mm の短繊維である．在来の金属繊維製造法であ る延伸法に比べてきわめて安価に金属繊維が得られる. 短繊維であるため, 樹脂と混練する場合コンパウンド法 によらなければならず，成形品中の繊維は甚だしい破損 を受けている. 従って, 十分なシールド効果を得るには, 10 体積\%程度の金属繊維を添加する必要があり, 成形 時の樹脂粘度が上昇し成形が困難となる。 また成形体の 比重が大きくなり, 軽量化と言ら樹脂の特徵が損なわれ る(5).

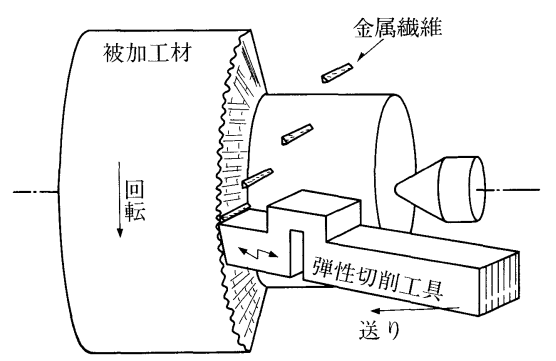

図 5 びびり振動切削法による金属繊維の製造法.

\section{（2）炭素䋐 維}

炭素繊維自体, $1.5 \times 10^{-5} \Omega \mathrm{m}$ と体積固有抵抗が低く, 熱可塑性樹脂に添加すると導電性が発現する. しかし, 金属繊維と比較した場合の導電性はかなり低く，炭素繊 維は帯電防止などでは少量の添加でよいが，電磁波シー ルドの目的では約20体積\%以上の添加量が必要である. その結果, 成形時の流動性が低下し, 成形体のアイゾッ ト衝撃值も低下する(7)(28).

\section{（3）金属化炭素繊維}

金属化炭素繊維は，導電性向上の目的から，炭素繊維 表面に電解メッキを施したものである。体積固有抵抗は $10^{-7} \Omega \mathrm{m}$ と金属並，比重はアルミニウム程度である。
メッキに用いる金属としては，銅，ニッケルであるが， 耐食性の面から銅単独で用いられることは少ない，炭素 繊維そのものが脆性材料であるため, 金属化炭素繊維も 破損し易く，成形時にメッキ層が剥離することもある. 従って，充分なシールド効果を得るには，10体積\%程 度樹脂に混練する必要があり, 成形時の流動性が低下寸 る. 金属化炭素繊維は, 現段階では，かなり高価な材料 である(7) (26) (28).

\section{（4）金属化ガラス繊維(29)(31)}

ガラス繊維の表面にニッケル合金を無電解メッキした ものであり，体積固有抵抗は $10^{-5} \sim 10^{-7} \Omega \mathrm{m}$ と高い導 電性を示し，耐食性の高い金属で保護被膜が形成されて いる. 比重は3.2〜4.1である. ガラス繊維そのものが脆 性材料であるため, 成形材料として 3 ないし $6 \mathrm{~mm}$ 長 のチョップドストランドを用いても, 射出成形により $0.3 \sim 0.6 \mathrm{~mm}$ になる. 成形体の体積固有抵抗を $10^{-2} \sim$ $10^{-3} \Omega \mathrm{m}$ とするには, 熱可塑性樹脂に $10 \sim 15$ 体積\%の 金属化ガラス繊維を混練成形する必要がある. 成形品比 重もかなり大きくなる.

\section{（5）銅 繊 維}

銅繊維は金属繊維の中でも最も電気抵抗が小さく，価 格も比較的安価な繊維のひとつである. 連続繊維である ため繊維長を長く保つのに有利なマスターペレット方式 が用いられる。 しかし, 繊維そのものの強度が低く, 成 形時に, 繊維切断が生じる. 従って十分なシールド効果 を得るにはやはり 15 質量\%程度の金属繊維を添加する 必要があり, 成形性が悪くなるのみならず, 成形品の比 重も大きくなる，最近では，銅繊維と低融点合金を含有 したマスターペレットが上市されている。成形と同時 に，低融点合金が銅繊維同士を接触させ，接触抵抗の低 減, 冷熱サイクル時のシールド効果の低下防止に役立っ ている(27). 銅はポリプロピレン樹脂等一部の樹脂を分 解するため，用いる樹脂が限定される.

\section{（6）ステンレス鋼繊維}

ステンレス鋼繊維の製造工程を図 6 に示す。ステン レス鋼棒線を, 銅あるいは軟鋼で被覆, 集束し, ダイス で所定の繊維径まで引き抜く，引き抜き後，鞘となる金 属を酸洗により除去し，ステンレス鋼繊維束が得られ

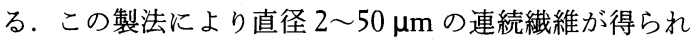
る.

連続繊維であるため, 繊維破損が最小限となるマスタ 一ペレット方式が適用できる．ステンレス鋼繊維の最大 の特徵は, 少ない添加量で十分なシールド効果が発揮で きることである．僅か 1 体積\%程度で十分なシールド 効果が得られる（図 7)。これは，成形体中の䋐維が700 以上といら高い平均アスペクト比を保っていることによ 


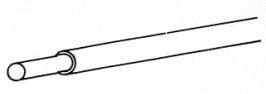

（1）被覆

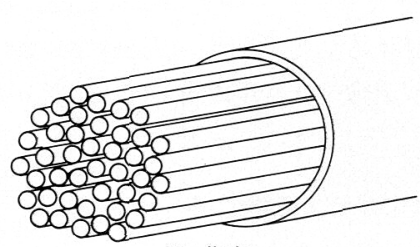

(2) 集束

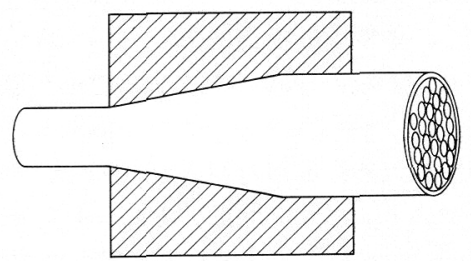

(3) 引き抜き

図6 ステンレス繊維の製造法(32).

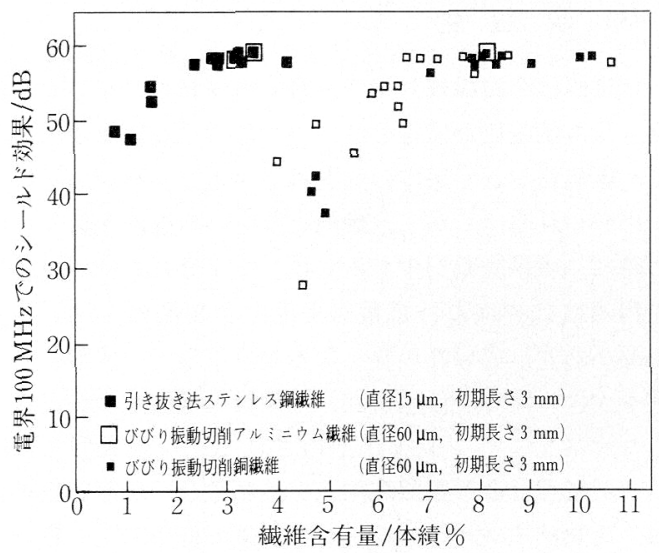

図 7 添加量とシールド効果.

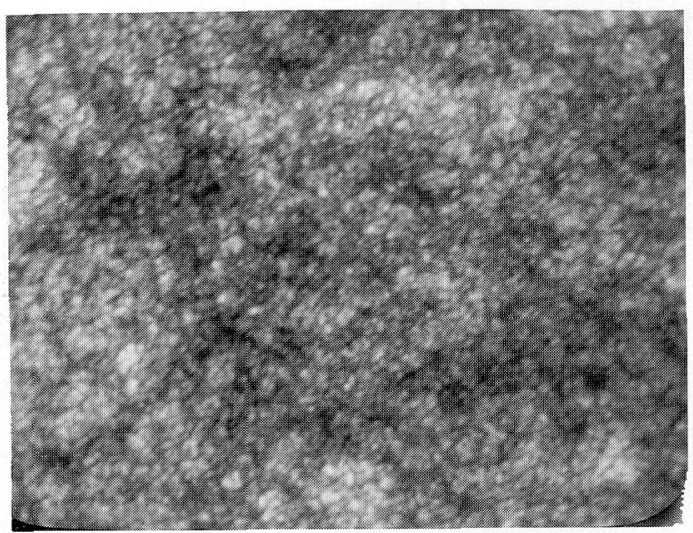

図 8 成形品中のステンレス絨維 (X 線透過写真)

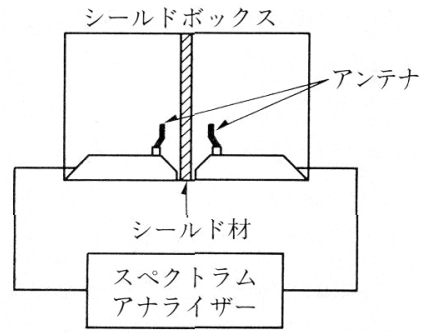

戍ソ(株アドバンテスト法。

るものである(17). ステンレス鋼としては通常 SUS304 あるいは316Lを使用するため，腐食の心配が無い。金 属繊維を用いた電磁波シールド材の場合, 冷熱サイクル によりそのシールド効果が低下する問題が心配されてい る。これは，マトリクスとなる樹脂と金属繊維との熱膨 張係数か大きく異なるためである(19)(33). ステンレス鋼 緎維に関しては，図８に示すように，ステンレス鋼緎 維同土が複雑に絡まりあっているために, シールド効果 の低下は比較的小さい。また冷熱サイクルによるシール ド効果の低下は，マトリクス樹脂の耐熱性と大きく関わ りがある。がラス繊維等の無機〉ィラーの添加，耐熱性 樹脂とのポリマーブレンドによりマトリクス樹脂の耐熱 性を向上させることで，シールド効果の低下を極力抑兄 ることが可能である(17).

\section{5. 測 定 法 ${ }^{(34)(35)}$}

最終製品の評価は，電気回路を組み込んだ状態で，才 ープンサイトあるいは電波暗室で行ら必要がある(36). しかしながら、シールド材開発のらえで上記の試験を行 らことは困難であるため，いくつかの簡易測定法が考案 されている，最も簡単な測定法としては体積固有抵抗の 測定がある。シールド効果の測定法としては, トランス ミッションライン法 ${ }^{(34)}$,デェアルチャンバー法(37) (侏) ドバンテスト法等がある。図 9 に(株アドバンテスト法 を示す。この方法は，わが国でもっとも一般的な簡易測 定法ではあるが， $500 \mathrm{MHz}$ 以上の周波数領域では共鳴 を起こすためにデータの信頼性に欠ける，ステンレス鋼 繊維複合体に限ってみれば, $10 \mathrm{GHz}$ の電波の反射強度 を測定するBEKISCAN 法がある(38).

\section{6. おわりに}

これまで電磁波シールドの市場では，導電性塗料，無 電界メッキが優位な立場にあった。昭和63年12月から, VCCI の規制も本格的に始まり，ユーザー各社の電磁波 シールドに詨する取り組みが，本格化している．成形材 料は，従来の製造ラインをそのまま利用できると言う点 で, コスト的に極めて有利であり，今後大きく伸びてい 
くものと期待されている，その実現には，材料メ一カ 一, 成形メーカー，製品メーカーの三者がー致協力する

ことが必要である.

\section{文献}

（1）情報処理等電波障害自主協議会：情報処理装置及び電 子事務用機器等から発生する妨害波の自主規制措置運 用規定.

（2）坂本幸夫，山本秀俊：電子技術，30(8) (1988), 28 。

（3）佐藤由郎：電子技術，30(8) (1988), 19.

（4）神戸徳蔵, 熊谷八百三, 卜部啓：防錆管理, 31 (1987), 316

（5）日経ニューマテリアルズ，1987年 9 月26日号，74.

(6) S. A. Schelkunoff: 電磁波論, 岩波, (1964).

( 7 ) D. M. Bigg: Adv. Polym. Technol., 4(3/4) (1984), 255.

（8）佐藤弘三：充てん高分子の物性, 理工出版, (1978).

( 9 ) M. T. Kortshot and R. T. Woodhams: Polym. Compos., 9 (1988), 60.

(10) F. Carmona, F. Barreau, P. Delhae and P. Canet: J. Physique Lett., 41 (1980), 531.

(11) J. Boissonade, F. Barreau and F. Carmona: J. Phys. A: Math, Gen., 16(1983), 2777.

(12) 前田 修，山木準一，片山祐三：高分子論文集, $32(1975), 42$

（13）大野 亮：日本ゴム協会誌， 57(1984), 178 .

(14) Y. Shimizu, M. Sumita, N. Miyadera and K. Miyasaka: Sen-i Gakkaishi, 42(1986), T-261.

(15) K. Miyasaka, K. Watanabe, E. Jojima, H. Aida, M. Sumita and K. Ishikawa: J. Mater. Sci., 17 (1982), 1610.

（16）住田雅雄：日本接着協会誌，23(1987)，103.
（17）高濱裕宣，玉木裕士，戸来稔雄：製鉄研究, 330 (1988), 24.

(18) J. J. Reilly, S. J. Thoman and W. W. Lin: SAMPE J. Jan./Feb. (1987), 22.

(19) S. K. Bhattacharya and A. C. D. Chaklader: Polym.Plast. Technol. Eng., 19(1) (1982), 21.

（20）林 盛彦：名試研 研究報告, 70(1985), 1 .

(21) 林 盛彦：機能性材料, 5(11) (1985), 26.

(22) 山田久志, 成田道郎：プラスチックスエージ，1988年 4 月号, 164

(23) D. M. Bigg: Polym. Compos., 6(1985), 20

(24) D. A. Janeczek: ANTEC '86, (1986), 226.

（25）岩瀬英裕：東芝レビュー, 41 (2) (1986), 122.

（26）久保誠六, 酒井 伸, 伊藤 健, 西村哲夫：長野県工 試研究報告, No. 7 (1987), 9.

（27）小池 測：プラスチック成形技術，5(2) (1988), 21.

（28）中間克美，大北雅：強化プラスチックス, 32 (1986), 469.

（29）大塚晴彦, 新井重治, 伊勢田 徹 : 旭硝子研究報告, 37 (1) (1987), 157.

(30) 林 寿雄 : プラスチックス, 35(7) (1984), 25.

（31）大塚晴彦, 新井重治, 二宮佑八，川島貞男：強化プラ スチックス, 32(1986), 269.

（32）白鳥信令 : 繊維学会誌, 44(1988), 237.

（33）梅崎義臣, 大崎徹郎, 田代計助, 石崎正見, 山上良 彦：福岡県福岡工業試験所研究報告, (1986), 142 .

（34）「ノイズ対策最新技術」編集委員会：ノイズ対策最新 技術，総合技術出版，(1986).

(35) 右馬野雅弘：工業材料, 36(4) (1988), 61.

（36）増田知彦：工業材料, 36(4) (1988), 71.

(37) D. M. Bigg, W. Mirick and D. E. Stutz: Polymer Testing, 5 (1985), 169.

(38) J. Samyn, P. Deceuninck: ANTEC '86, (1986), 282.

掲 示 板

\section{International Congress on Intergranular and Interface} Boundaries in Materials

時：1989年 9 月 4 日(月) 8 日 (金)

所 : Ecole des Mines de Paris, France

アブストラクト締切：1989年 2 月

登録締切: 1989年 5 月

問合先 : $\overline{1} 106$ 東京都港区六本木7-22-1

東京大学生産技術研究所 石田洋一

TEL : 03-402-6231 内線 2440

FAX : 03-402-6350 